\title{
BENCHMARKING WEBSITE E-COMMERCE PRODUK PENGOLAHAN PANGAN UNGGULAN KOTA MALANG SEBAGAI SARANA PENINGKATAN KUALITAS LAYANAN MENGGUNAKAN WEBQUAL 4.0
}

\author{
Miftakhur Rokhman ${ }^{1}$, Yosep Agus Pranoto ${ }^{2}$, Kartiko Ardi Widodo ${ }^{3}$ \\ ${ }^{1,2)}$ Teknik Informatika, Institut Teknologi Nasional Malang \\ 3) Teknik Elektro, Institut Teknologi Nasional Malang \\ moh.miftakhur.rokhman@gmail.com
}

\begin{abstract}
ABSTRAK
Indonesia pada tahun 2015 tergabung dalam komunitas ekonomi negara-negara kawasan ASEAN yaitu ASEAN Economic Community (AEC) atau biasa disebut Masyrakat Ekonomi ASEAN (MEA). ASEAN menyepakati bahwa pelaksanaannya diarahkan pada integrasi ekonomi kawasan yang mengacu pada AEC Blueprint dimana disebutkan bahwa ASEAN sebagai kawasan dengan daya saing ekonomi tinggi dengan salah satu elemennya adalah e-commerce

Semakin banyaknya industri mikro,kecil dan menengah di wilayah kota Malang berkompetisi memasarkan produk ungulan dimana salah satu cara melakukan penetrasi pasar ke konsumen adalah dengan media e-commerce yang menggunakan metode B2C. Penelitian ini bertujuan untuk mengukur kualitas layanan website e-commerce terutama pada bidang penjualan produk unggulan di wilayah kota Malang dengan menggunakan instrumen dari WebQual 4.0 untuk mendapatkan data kualitas layanan $e$-commerce dari konsumen. Importance Performance Analysis (IPA), merupakan sebuah alat bantu yang digunakan dalam melakukan analisis atau yang berguna untuk melakukan proses perbandingan sampai sejauh mana antara kinerja/pelayanan yang dapat dirasakan oleh pengguna jasa dibandingkan terhadap tingkat kepuasan yang diinginkan. Tingkat kesesuaian hasil perbandingan antara skor kinerja pelaksanaan dengan skor kepentingan, sehingga tingkat kesesuaian inilah yang akan menentukan skala perioritas yang akan dipakai dalam penanganan faktor-faktor yang mempengaruhi kepuasan pengguna

Berdasarkan hasil evaluasi kualitas layanan website UMKM dengan menggunakan instrumen WebQual 4.0 dan metode Importance-Performance Analysis (IPA), maka dapat diambil kesimpulan bahwa kualitas website UMKM di Malang belum sesuai dengan harapan pengguna. Terdapat perbedaan yang memperlihatkan adanya kesenjangan (gap) antara dua perspektif penilaian antara tingkat kinerja (performance) atau kualitas aktual yang dirasakan oleh pengguna dan tingkat kepentingan (importance) atau kualitas ideal yang diharapkan. Secara keseluruhan, selisih dari kedua perspektif penilaian ini atau gap bernilai negatif dengan nilai sebesar -0.091 . Berdasarkan penilaian ketiga dimensi pengukuran, dimensi usability memiliki nilai selisih -0.081 , dimensi Service Interaction memiliki nilai selisih atau gap sebesar -0. 083 dan dimensi Information Quality memiliki nilai selisih atau gap paling besar sebesar -0.109. Berdasarkan hal tersebut dapat disimpulkan bahwa kualitas aktual yang dirasakan belum bisa memenuhi kualitas ideal yang diinginkan pengguna website UMKM di Malang terutama dari atribut kualitas yang berhubungan dengan informasi dalam website.
\end{abstract}

Keyword : WebQual 4.0, e-commerce, Importance-Performance Analysis Masyarakat Ekonomi ASEAN

\section{PENDAHULUAN}

Saat ini internet merupakan kebutuhan primer para masyarakat di metropolitan dan kaum urban di kota - kota besar dan berkembang,hal ini seiring dengan pertumbuhan ekonomi yang menjadikan alat telekomumikasi yang menggunakan media internet bukan lagi segai kebutuhan gaya hidu tetapi sebagai kebutuhan primer.

Saat ini internet bukan lagi sebagai media yang hanya berfungsi sebaga media penyedia informasi ,tetapi merambah sebagai media bisnis yang sangat strategis.revolusi penggunaan internet dari sebagai penyedia informasi menjadi media dalam memenuhi kebutuhan bisnis dan pengguna internet ini terrus berevolusi berkembang yang tadinya hanya sebagai alat pertukaran informasi dalam hal bisnis menjadi alat untuk strategi bisnis yang efisien.

Beberapa strategi bisnis yang lazim digunakan para pengguna internet yaitu dalam bidang pemasaran, penjualan, dan pelayanan pelanggan.hal ini sangat beralasan karena dengan menggunakan media internet akan membuang segala batasan batassan yang sering terjadi pada proses bisnis perdagangan seperti batasan dalam jarak,ruang ,dan waktu.

pemasaran di internet layaknya perdangan dengan model direct marketing,dimana dalam hal ini para konsumen barang yang berhubungan langsung dengan penjual baik itu penjual satuan maupun grosir dan walaupun penjualnya berada di luar negeri serta pembelian dengan satuan masih bisa menurut Rhenal khasali bahwa Pengguna internet di seluruh dunia berkisar 200 juta, 67 juta diantaranya berada di Amerika Serikat,dan perkembangan pengguna internet di Indonesia akan berlipat menjadi dua kali setiap dalam rentang 100 hari (Rhenald,2000).

Berdasarkan referensi diatas didapat kesimpulan bahwa penggunaan internet untuk 
aplikasi strategi bisnis di Indonesia memiliki peluang yang sangat cukup besar, tapi banyak sekali pengguna yang tidak menyadari hal tersebut,karena pemain bisnis di Indonesia yang dalam skala besar masih banyak dari kalangan kalangan tua. Menurut pendapat Rhenald Pasar internet adalah pasar orang muda, bukan orang tua.

Penggunaan internet di Indonesia digunakan untuk keperluan bisnis sebesar: 43\%, sedangkan keperluan pribadi sebanyak: 32\% (Nielsen, 1999). Penggunaan internet di Indonesia untuk keperluan bisnis sebesar 43\%, menunjukkan beberapa perusahaan telah menerapkan internet untuk berbisnis, yang dikenal dengan E-Business atau Ecommerce(yuliana ,2004).

Business to Customer (B2C) merupakan sebuah kegiatan e-business atau bisnis yang ilakukan dengan media internet yang dimana dilakukan secara langsung oleh perusahaan atau produsen kepada konsumen personal atau secara individu, dimana kegiatan transaksi tersebut secara umum menggunakan mekanisme toko online (online shop) yang menjadi storefront serta berisikan katalog produk yang akan ditawarkan. Dengan transaksi penjualan langsung di internet dan reservasi pemesanan dapat langsung di lakukan oleh konsumen karena informasimengenai detail info produk sudah tercantum pada halaman katalog produk. .(Himawan ,2015)

Kota Malang merupakan sebuah kota yang terletak di kota jawa timur .kota ini berbatasan langsung dengan wilayah wilayah strategis perdagangan lain seperti surabaya,mojokerto,pasuruan,blitar diamana kota kota tersebut nerupakan kota - kota dengan jumlah industri-industri besar barang yang sangat banyak. selain itu karena keaneka ragaman penduduk dan terkenal sebagai kota pelajar terbesar di jawa timur menjadikan kota ini menjadi kota kretif oleh karena hal tersebut kota Malang boleh dikatakan merupakan sentra bisnis kreatif yang merupakan salah satu terbesar di wilayah jawa timur yang menjadikan kota Malang sebagai trend setter bisnis kretif di jawa timur .

Berdasar data statistik yang diperoleh dari dinas koperasi dan UMKM kota Malang, jumlah UMKM di Kota Malang mencapai 113 ribu unit.Jumlah ini naik dibandingkan tahun 2014 yang mencapai 77 ribu unit. Dari data tersebut sebanyak 87 persen atau sekitar 99 ribu unit masuk kategori usaha mikro yang memiliki omzet kurang dari Rp 300 juta setahun dan sisanya terbagi dalam kelompok kecil (omzet Rp 300 juta - Rp 1 miliar), dan menengah (omzet di atas Rp 1 miliar setahun). Dengan adanya ribuan UMKM itu membuat Dinas Koperasi serius untuk mendampingi UMKM hal tersebut dilakukan karena untuk menjaga agar UMKM tetap bertahan. Dikarenakan UMKM terbukti menjaga pondasi perekonomian, bahkan ketika sedang krisis. Artikel ini telah tayang di
suryaMalang.com dengan judul UMKM Kota Malang Terus Tumbuh di Tengah Kendala Klasik, http://suryaMalang.tribunnews.com/2018/04/14/um km-kota-Malang-terus-tumbuh-di-tengah-kendalaklasik.

Analisis yang disebut Importance Performance Analysis (IPA) diperkenalkan pertama kali oleh Martilla dan James apada tahun 1977. Importance Performance Analysis (IPA), merupakan sebuah alat bantu yang digunakan dalam melakukan analisis atau yang berguna untuk melakukan proses perbandingan sampai sejauh mana antara kinerja/pelayanan yang dapat dirasakan oleh pengguna jasa dibandingkan terhadap tingkat kepuasan yang diinginkan. Tingkat kesesuaian hasil perbandingan antara skor kinerja pelaksanaan dengan skor kepentingan, sehingga tingkat kesesuaian inilah yang akan menentukan skala perioritas yang akan dipakai dalam penanganan faktor-faktor yang mempengaruhi kepuasan pengguna (Yola,2013)

Untuk memperbaiki suatu kualitas layanan e -commerce dalam sebuah produk perlu dilakukan adanya suatu benchmarking atau penilaian denagan membandingkan satu atau lebih subjek peneleitian yang sejenis.dalam hal ini adalah e-commerce B2C yang nantinya hasil benchmarking ini akan bermanfaat bagi konsumen dan perusahaan. Ada dua tipe untuk benchmarking yang sering digunakan untuk menilai B2C. Pertama, benchmarking ecommerce B2C yang dapat membantu konsumen untuk memilih tempat berbelanja yang sesuai dengan kebutuhannya. Kedua, adanya benchmarking ecommerce B2C yang dapat membantu pelaku bisnis untuk menilai kuliatas layanan e-commerce B2C yang dimilikinya sehingga dapat memberi layanan yang terbaik kepada konsumen.

Benchmarking adalah sebuah alat untuk mengevaluasi produk, layanan, dan proses kerja organisasi sebagai representasi praktiknya yang bertujuan untuk perbaikan organisasi (Kabir dan Hasin 2012). Dengan adanya proses benchmarking hal ini dapat membantu proses audit layanan ecommerce B2C perusahaan dan membantu konsumen dalam memilih perusahaan untuk memenuhi kebutuhannya. Benchmarking merupakan proyek pada banyak perusahaan sebagai alat untuk audit perusahaan.

Berdasarkan latar belakang masalah yang telah diuraikan di atas, maka rumusan permasalahan dalam penelitian ini adalah sebagai berikut:

a. Bagaimana pihak penyedia layanan e comerce memperoleh feedback terhadap user website_e commerce yang dikelola

b. Apakah website layanan e-commerce yang menjadi ujung tombak penjualan online produk unggulan asli Malang telah memenuhi kebutuhan pengguna.

Adapun batasan masalah pada penelitian ini adalah: 
1. Website e-commerce yang dianalisis adalah website e-commerce yang berasal dari Malang .

2. Menggunakan teknik Importance Performance Analysis (IPA) untuk mengukur kualitas layanan website e-commerce.

\section{TINJAUAN PUSTAKA}

\subsection{Internet Dalam Bisnis}

Penggunaan internet dalam dunia bisnis bisanya digunakan untuk peertukaran informasi ,katalog dari produk,sebagai media promosi,surat elekronik, buletin boards,kuisioner elektronik serta mailing list.internet sebagai media komunikasi dalam bisnis juga dapat digunakan untuk kegiaatan diskusi,dialog,dan konsultasi secara online,sehingga konsumen dapat terlibat secara proaktif dalam perancangan,pengembangan,pemasaran ,serta penjualan produk secara interaktif.secara umum pemasaran dalam menggunakan media pustaka menggunakan dua cara yaitu push and pull marketing.keuntungan penggunaan internet dala bisnis yaitu komunikasi secara global yang dapat dilakukan secara interaktifinformasi, layanan yang diperoleh konsumen seusuai dengan kebutuhan yang di kehendaki oleh konsumen,serta aktifitas perdaganangan dapat disninergikan secara online. Aplikasi Electronic dalam perdagangan yang dikenal sebaga E-Commerce ada dua model, yaitu: Business-to-Consumer dan Business-to-Business Commerce, dimana pembayaran transaksi electronic commerce diatur dalam Sistem Electronic Funds Transfer (Yuliana, Oviliani,2004)

\subsection{Importance Performance Analysis(IPA)}

Dalam sebuah analisis yang disebut dengan IPA menyajikan bahwa manajemen selaku penyedia layanan yang bergerak dalam bidang website tidak selalu menilai kualitas keseluruhan layanan saja sebagaimana dipersepsikansebagian besar pengguna website ,tetapi dalam hal ini bisa digunakan juga untuk melakukan proses identifikasi beberapa dimensiyang menjadi kunci dan segala aspek dalam setiap dimensi (atribut/fitur) pada kualitas website yang membutuhkan penyempurnaan kualitas dimana dinilai berdasrkan hasil persepsi dan harapan pengguna.

Teknik dalam analisa IPA ini mencari hubungan antara tingkat kepentingan dan tingkat kepuasan melalui sebuah analisis penilaian terhadap skor gap atau kesenjangan.sehingga dalam sebuah organisasi tidak hanya menilai kulitas layanan yang dipersepsikan oleh pengguna yang telah melakukan penilaian,tetpi dapat jugan mengidetifikasi dimensi kunci dan aspek yang menjadi kunci yang membutuhkan perbaikan kualitas dari hasil persepsi dan harapan pengguna

\section{METODOLOGI PENELITIAN}

Metode penelitian yang digunakan dalam penelitian ini adalah kuantitatif dengan menggunakan pendekatan survey. Penelitian ini bertujuan untuk mengetahui kualtias layanan website e-commerce khusus yang ada diwilayah dengan menggunakan instrumen WebQual dan Importance Performance Analysis (IPA). Alur Penelitian merupakan tahapan dari penelitian yang diawali dengan tahap memulai hingga selesai seperti Gambar 1.

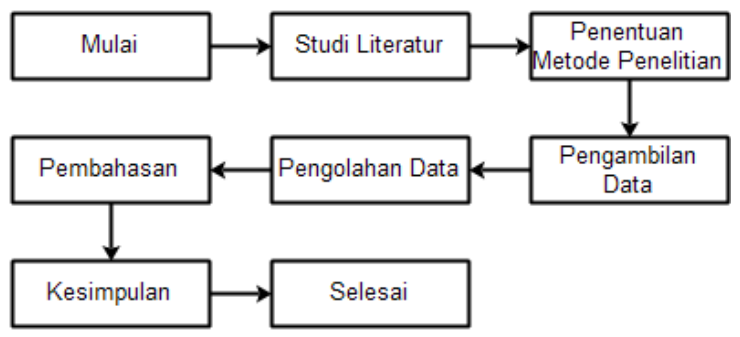

Gambar 1. Diagram Alir Penelitian

Studi literatur merupakan tahapan-tahapan dalam menggambarkan secera singkat sebuah penelitian yang telah ada untuk dipelajari untuk penetapan suatu topik. Studi literatur ini didapatkan melalui berbagai sumber, seperti: jurnal, buku, ebook, Internet, laporan penelitian.

Metode yang digunakan pada penelitian ini berupa WebQual 4.0 sebagai standart dalam kualitas situs yang memiliki 22 atribut didalamnya dan Importance-Performace Analysis (IPA) sebagai analisis.

Penelitian ini melibatkan sebanyak 75 responden selaku pengguna aktif internet. Responden mengisi kuesioner untuk penelitian ini, hasil kuesioner akan dianalisis dan didapatkan kualitas layanan terhadap website yang di teliti.

Kuesioner berupa pertanyaan-pertanyaan yang jawabannya berupa sekala nilai pengukuran antara 1 hingga 5 dengan keterangan nilai sebagai berikut:

a) Nilai 1 untuk "sangat tidak setuju"

b) Nilai 2 untuk "kurang setuju"

c) Nilai 3 untuk "cukup / netral"

d) Nilai 4 untuk "setuju"

e) Nilai 5 untuk "sangat setuju"

WebQual yang akan digunakan dalam penelitian ini adalah suatu metode yang digunakan untuk mengukur kualitas website berdasarkan persepsi dari pengguna terakhir melalui instrumeninstrumen tertentu. Instrumen WebQual disusun berdasarkan 3 dimensi yang kesemuanya adalah pengukuran kepuasan konsumen atau user terhadap kualitas dari website tersebut. Pada penelitian ini menggunakan WebQual sebagai kuesioner yang terdapat 22 atribut sebagai pentanyaan dalam kuesioner, kemudian kuesioner tersebut dibedakan 
menjadi 2 bagian penilaian yaitu berdasarkan kepentingan dan kinerja untuk dilanjutkan penilaian IPA.

Analisi IPA dilakukan dengan tujuan untuk pengukuran terhadap hubungan persepsi dengan peningkatan sebuah kualiatas akan produk atau jasa yang kemudian dimasukkan kedalam grafik yang dikenal dengan analisis kuadran. Hasil dari pengukuran terhadap metode ini akan ditampilkan dalam bentuk grafik yang terbagi atas empat bagian, dimana garis $\mathrm{X}$ sebagai performance dan garis $\mathrm{Y}$ sebagai importance.

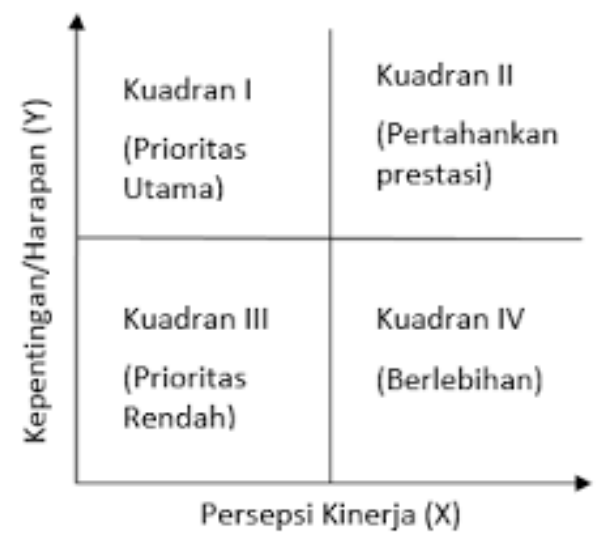

Gambar 2. Analisis Kuadran IPA

Dari analisis kuadaran yang ditunjukkan pada Gambar 2 maka dapat dilihat sebagai:

1) Kuadran I: Dimana hasil kepentingan tinggi dan kinerja dari situs rendah. Pada analisis kuadran ini merupakan yang harus diprioritaskan karena faktor-faktor yang termasuk kedalam kuadran ini adalah faktor yang penting namun belum dapat memberikan kepuasan terhadap pelayanan karena tingkat kinerjanya rendah, maka dari itu pihak manajemen dapat melakukan pengalokasian sumber daya pada kuadran ini.

2) Kuadran II: Dimana hasil kepentingan dan hasil kinerjanya sama-sama memiliki tingkatan yang tinggi. Faktor-faktor yang terdapat pada kuadran ini diharapakan pikah manajemen tetap mempertahankannya karena tingkat kepentingan dan kinerjanya tinggi.

3) Kuadran III: Dimana tingkat kepentingan dan kinerja terhadap faktor ini meiliki tingkatan yang rendah. Maka dari itu tidak perlu terlalu memperhatikan kuadran ini dikarena pengguna juga tidak terlalu mementingkanya.

4) Kuadran IV: Dimana tingkat kepentingan kecil namun kinerjanya besar. Pihak manajemen diharapkan dapat mengalokasikan faktor-faktor yang termasuk kedalam kuadran ini kepada kuadran lain karena tingkat kinerja pada kuadran ini terlalu berlebihan.

\section{ANALISIS DAN PEMBAHASAN}

Dimensi indikator yang digunakan dalam penelitian ini setelah dilakukan uji validitas dan uji realibilitas berserta dengan nilai performance dan importance masing-masing. indikator dibedakan menjadi dua jenis, yaitu kualitas yang saat ini dirasakan atau aktual terjadi yang disebut dengan (Performance) dan kualitas yang diharapkan dan dianggap penting untuk dikembangkan yang disebut dengan (Importance).

Tabel 1. Nilai Rata-rata Indikator

\begin{tabular}{|c|c|c|c|}
\hline Var. & Indikator & Per. & Imp. \\
\hline \multirow{9}{*}{ 尝 } & $\begin{array}{l}\text { [US1] Interaksi jelas } \\
\text { dan dapat dimengerti }\end{array}$ & 3.854 & 3.893 \\
\hline & $\begin{array}{l}\text { [US2] Mudah } \\
\text { melakukan navigasi }\end{array}$ & 3.796 & 3.903 \\
\hline & $\begin{array}{l}\text { [US3] Tampilan } \\
\text { menarik }\end{array}$ & 3.864 & 4.01 \\
\hline & $\begin{array}{l}\text { [US4] Desain sesuai } \\
\text { (toko online) }\end{array}$ & 4.068 & 4.165 \\
\hline & $\begin{array}{l}\text { [US5] Website } \\
\text { memiliki daya saing } \\
\text { terhadap website } \\
\text { sejenis }\end{array}$ & 4.165 & 4.223 \\
\hline & $\begin{array}{l}\text { [US6] Mudah } \\
\text { dipelajari dan } \\
\text { dioperasikan }\end{array}$ & 3.883 & 3.942 \\
\hline & $\begin{array}{l}\text { [US7] Website } \\
\text { memberikan } \\
\text { pengalaman positif }\end{array}$ & 3.922 & 3.835 \\
\hline & $\begin{array}{l}\text { [US8] Informasi yang } \\
\text { diberikan akurat }\end{array}$ & 3.65 & 3.796 \\
\hline & $\begin{array}{l}\text { [US9] Informasi yang } \\
\text { diberikan dapat } \\
\text { dipercaya }\end{array}$ & 3.971 & 4.136 \\
\hline \multirow{7}{*}{ 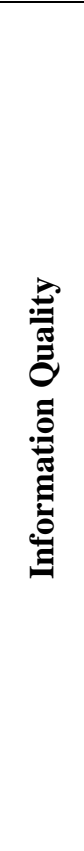 } & $\begin{array}{l}\text { [IQ1] Informasi yang } \\
\text { disajikan aktual }\end{array}$ & 3.767 & 3.786 \\
\hline & $\begin{array}{l}\text { [IQ2] Informasi yang } \\
\text { disajikan relevan }\end{array}$ & 3.903 & 4.01 \\
\hline & $\begin{array}{l}\text { [IQ3] Informasi yang } \\
\text { tersedia mudah } \\
\text { dimengerti }\end{array}$ & 3.767 & 3.883 \\
\hline & $\begin{array}{l}\text { [IQ4] Informasi dalam } \\
\text { website memiliki } \\
\text { tingkat detail yang } \\
\text { tepat }\end{array}$ & 3.883 & 3.99 \\
\hline & $\begin{array}{l}\text { [IQ5] Informasi di } \\
\text { website disajikan } \\
\text { dalam format yang } \\
\text { sesuai }\end{array}$ & 3.786 & 3.874 \\
\hline & $\begin{array}{l}\text { [IQ6] Toko online } \\
\text { memiliki reputasi } \\
\text { yang baik }\end{array}$ & 4.146 & 4.291 \\
\hline & $\begin{array}{l}\text { [IQ7] Website } \\
\text { memiliki keamanan } \\
\text { dalam bertransaksi }\end{array}$ & 4.243 & 4.388 \\
\hline
\end{tabular}




\begin{tabular}{|c|l|c|c|}
\hline & $\begin{array}{l}{[\text { [Q8] Website }} \\
\text { menjamin keamanan } \\
\text { informasi pribadi }\end{array}$ & 3.932 & 4.078 \\
\hline \multirow{2}{*}{} & $\begin{array}{l}\text { [SI1] Dalam website } \\
\text { tersedia } \\
\text { ruang/halaman } \\
\text { personalisasi }\end{array}$ & 3.961 & 4.165 \\
\cline { 2 - 4 } & $\begin{array}{l}\text { [SI2] Pelaksanaan } \\
\text { layanan sesuai dengan } \\
\text { janji }\end{array}$ & 3.67 & 3.728 \\
\cline { 2 - 4 } & $\begin{array}{l}\text { [SI3] Website } \\
\text { memberikan } \\
\text { kemudahan } \\
\text { berkomunikasi } \\
\text { dengan perusahaan }\end{array}$ & 3.573 & 3.68 \\
\hline \multirow{2}{*}{} & $\begin{array}{l}\text { [SI4] Website } \\
\text { memberikan layanan } \\
\text { berbentuk komunitas }\end{array}$ & 3.845 & 3.971 \\
\cline { 2 - 4 } & $\begin{array}{l}\text { [SI5] Website Mudah } \\
\text { untuk Digunakan }\end{array}$ & 3.748 & 3.67 \\
\hline
\end{tabular}

Keterangan

Var. = Variabel

Per. $=$ Performance

Imp. $=$ Importance

Analisis kesenjangan (gap) dilakukan untuk melihat tingkat kualitas dari website UMKM di Malang yang ditinjau dari nilai kesenjangan (gap) antara kualitas yang dirasakan (aktual) dan kualitas yang diinginkan atau diharapkan (ideal). Kualitas aktual ditunjukan melalui penilaian responden terhadap kinerja (performance) atribut indikator pembentuk kulitas website berdasarkan dimensi indikator Webqual, sedangkan kualitas ideal ditunjukan berdasarkan penilaian responden terhadap tingkat kepentingan atau harapan (importance) dari atribut indikator kualitas tersebut. Proses untuk menentukan nilai kesenjangan (gap) dapat dihitung dari selisih nilai antara nilai kualitas website aktual (Performance) dan kualitas website ideal (Importance).

Keterangan :

$$
\text { Qi (Gap) }=\text { Perf(i) }-\operatorname{Imp}(\mathrm{i})
$$

Qi (Gap) = tingkat kesenjangan kualitas

Perf(i) = nilai kualitas yang dirasakan saat ini atau aktual (performance)

Imp(i) = nilai kualitas ideal atau harapan dan penting untuk dikembangkan (importance)

Tingkat kualitas yang baik ditandakan dengan nilai positif atau Qi (gap) $\geq 0$. Hal ini menandakan kualitas actual telah memenuhi kualitas ideal yang diharapkan oleh para responden. Sebaliknya bila hasil Qi (gap) < 0 atau bernilai negative, maka tingkat kualitas dinyatakan kurang dan belum dapat memenuhi keinginan ideal dari pengguna. Penjelasan kesenjangan dimensi indikator kualitas diuraikan dalam masing-masing dimensi yaitu usability, information dan service interaction.

Tabel 2 Tabel nilai kesenjangan variabel usability

\begin{tabular}{|l|l|c|c|c|}
\hline Variabel & Indikator & Perf. & Imp. & $\begin{array}{c}\text { Qi } \\
\text { (Gap) }\end{array}$ \\
\hline & US1 & 3.854 & 3.893 & -0.039 \\
\cline { 2 - 5 } & US2 & 3.796 & 3.903 & -0.107 \\
\cline { 2 - 5 } & US3 & 3.864 & 4.01 & -0.146 \\
\cline { 2 - 5 } & US4 & 4.068 & 4.165 & -0.097 \\
\cline { 2 - 5 } Usability & US5 & 4.165 & 4.223 & -0.058 \\
\cline { 2 - 5 } & US6 & 3.883 & 3.942 & -0.059 \\
\cline { 2 - 5 } & US7 & 3.922 & 3.835 & 0.087 \\
\cline { 2 - 5 } & US8 & 3.65 & 3.796 & -0.146 \\
\cline { 2 - 5 } & US9 & 3.971 & 4.136 & -0.165 \\
\hline
\end{tabular}

Tabel 2 diatas menunjukan nilai kesenjangan (gap) indikator dalam dimensi usability. Berdasarkan tabel diatas tersebut, dapat dilihat bahwa nilai selisih antara kualitas aktual (performance) dan kualitas ideal (importance) hampir dari semua indikator bernilai negatif kecuali pada indikator "Website memberikan pengalaman positif". Nilai selisih rata-rata gap sebesar -0.081 . Indikator yang memiliki gap terbesar adalah pada indikator "Informasi yang diberikan dapat dipercaya" dengan selisih gap sebesar -0.165.

Tabel 3 Tabel nilai kesenjangan variabel information quality

\begin{tabular}{|c|c|c|c|c|}
\hline Variabel & idktr & Perf. & Imp. & Qi(Gap) \\
\hline \multirow{8}{*}{$\begin{array}{c}\text { Information } \\
\text { Quality }\end{array}$} & IQ1 & 3.767 & 3.786 & -0.019 \\
\hline & IQ2 & 3.903 & 4.01 & -0.107 \\
\hline & IQ3 & 3.767 & 3.883 & -0.116 \\
\hline & IQ4 & 3.883 & 3.99 & -0.107 \\
\hline & IQ5 & 3.786 & 3.874 & -0.088 \\
\hline & IQ6 & 4.146 & 4.291 & -0.145 \\
\hline & IQ7 & 4.243 & 4.388 & -0.145 \\
\hline & IQ8 & 3.932 & 4.078 & -0.146 \\
\hline \multicolumn{2}{|c|}{ Rata-rata } & 3.928 & 4.038 & -0.109 \\
\hline
\end{tabular}

Tabel 3 diatas menunjukan nilai kesenjangan (gap) indikator dalam dimensi information quality. Berdasarkan tabel diatas tersebut, dapat dilihat bahwa nilai selisih antara kualitas aktual (performance) dan kualitas ideal (importance) dari semua indikator bernilai negatif. Nilai selisih ratarata gap sebesar -0.109. Indikator yang memiliki gap terbesar adalah pada indikator "Website menjamin keamanan informasi pribadi" dengan selisih gap sebesar -0.146 . 
Tabel 4 Tabel nilai kesenjangan variabel Service Interaction

\begin{tabular}{|c|c|c|c|c|}
\hline Variabel & Idktr & Perf. & Imp. & Qi(Gap) \\
\hline \multirow{5}{*}{$\begin{array}{c}\text { Service } \\
\text { Interaction }\end{array}$} & SI1 & 3.961 & 4.165 & -0.204 \\
\hline & SI2 & 3.67 & 3.728 & -0.058 \\
\hline & SI3 & 3.573 & 3.68 & -0.107 \\
\hline & SI4 & 3.845 & 3.971 & -0.126 \\
\hline & SI5 & 3.748 & 3.67 & 0.078 \\
\hline \multicolumn{2}{|r|}{ Rata-rata } & 3.759 & 3.843 & -0.083 \\
\hline
\end{tabular}

Tabel 4 diatas menunjukan nilai kesenjangan (gap) indikator dalam dimensi Service Interaction. Berdasarkan tabel diatas tersebut, dapat dilihat bahwa nilai selisih antara kualitas aktual (performance) dan kualitas ideal (importance) hampir dari semua indikator bernilai negatif kecuali pada indikator "Website Mudah untuk Digunakan" dengan nilai gap 0.078. Nilai selisih rata-rata gap sebesar -0.083. Indikator yang memiliki gap terbesar adalah pada indikator "Dalam website tersedia ruang/halaman personalisasi" dengan selisih gap sebesar -0.204 .

Tabel 5 Tabel kesenjangan semua variabel dengan metode WebQual

\begin{tabular}{|l|c|c|c|}
\hline \multicolumn{1}{|c|}{ Variabel } & $\begin{array}{c}\text { Perfor } \\
\text { mance }\end{array}$ & $\begin{array}{c}\text { Impor } \\
\text { tance }\end{array}$ & $\begin{array}{c}\text { Qi } \\
\text { (Gap) }\end{array}$ \\
\hline Usability & 3.908 & 3.989 & -0.081 \\
\hline $\begin{array}{l}\text { Information } \\
\text { Quality }\end{array}$ & 3.928 & 4.038 & -0.109 \\
\hline $\begin{array}{l}\text { Service } \\
\text { Interaction }\end{array}$ & 3.759 & 3.843 & -0.083 \\
\hline Rata-rata & 3.865 & 3.957 & -0.091 \\
\hline
\end{tabular}

Tabel 5 diatas menunjukan nilai kesenjangan atau gap dari ketiga dimensi WebQual 4.0. Berdasarkan tabel diatas, secara keseluruhan, nilai selisih antara kualitas aktual (performance) dan kualitas ideal (importance) memiliki nilai negatif. Nilai selisih rata-rata sebesar -0.091. Dimensi yang memiliki gap terbesar adalah Information Quality dengan selisih sebesar -0.109. Hasil tersebut menunjukan nilai negatif atau $\mathrm{Q}<0$ yang berarti bahwa kualitas aktual yang dirasakan saat ini belum dapat memenuhi kualitas ideal yang diinginkan pengguna, maka tingkat kualitas dinyatakan masih buruk. Importance performance analysis (IPA) digunakan untuk melihat indikator kualitas website mana saja yang telah sesuai dengan keinginan pengguna dan mana saja yang membutuhkan perbaikan. Hasil dari analisis IPA menunjukan letak masing-masing indikator dalam matrix IPA yang terdiri dari empat kuadran. Proses dalam menentukan kordinat untuk setiap indikator, digunakanlah nilai rata-rata pembobotan indikator dari Tabel 4.26. Berikut ini Gambar 4.2 yang menunjukan posisi indikator dalam grafik matrix
IPA, dimana masing -masing dimensi digambarkan dengan masing-masing label

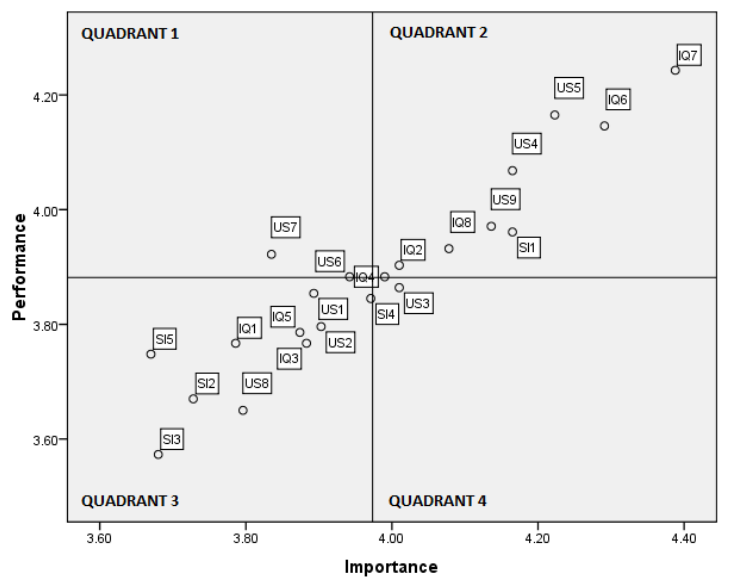

Gambar 3 Diagram Importance Performance Analysis (IPA)

Berdasarkan grafik IPA di atas dapat dilihat kedudukan masing-masing indikator di dalam matrix IPA. Setiap kuadran memiliki interpretasi spesifik yang menjelaskan tindakan strategis apa yang sebaiknya dilakukan untuk setiap indikator. Berdasar posisi indikator dalam masing-masing kuadran dapat disimpulkan bahwa indikator US7 terletak dalam kuadran I yang adalah indikator yang belum sesuai dengan harapan pengguna dimana indikator ini dinilai memiliki tingkat kepentingan yang tinggi namun tingkat kinerjanya dinilai rendah sehingga indikator dalam kuadran ini merupakan prioritas utama perbaikan. IQ2, IQ6, IQ7, IQ8, US4, US5, US9 dan SI1 terletak pada kuadran II, dimana indikator ini dinilai sebagai indikator yang memiliki tingkat kepentingan tinggi dan tingkat kinerjanya pun sudah baik. Indikator-indikator yang terletak dalam kuadran ini adalah indikator yang sudah sesuai dengan keinginan pengguna dan harus dipertahankan. US1, US2, US8, IQ1, IQ3, IQ5, SI2, SI3, dan SI5 terletak pada kuadran III. Indikatorindikator ini dinilai sebagai indikator yang memiliki tingkat kepentingan rendah dan tingkat kinerjanya pun tidak terlalu dirasakan baik oleh pengguna. Indikator-indikator yang terletak dalam kuadran ini adalah indikator yang dirasa cukup sesuai dan bukan merupakan prioritas utama perbaikan. Namun IQ4 berada pada posisi yang berada ditengah-tengah kuadran II dan IV dan memiliki tingkat kepentingan tinggi dan tingkat kinerjanya sudah baik, serta memiliki tingkat kinerja yang rendah namun kinerja sudah dinyatakan baik oleh pengguna. US3 terletak pada kuadran IV dimana indikator-indikator ini dinilai memiliki tingkat kepentingan yang rendah namun tingkat kinerjanya sudah dinilai sangat baik oleh pengguna. Indikator-indikator ini adalah indikator yang dinilai telah jauh melampaui harapan pengguna dan bisa sedikit diabaikan.

Berdasarkan hasil penelitian ditemukan bahwa terdapat perbedaan nilai rata-rata antara penilaian 
terhadap tingkat kinerja (performance) yang dirasakan atau kualitas aktual dengan tingkat kepentingan (importance) yang diinginkan atau kualitas ideal pengguna website UMKM. Hal ini menunjukan adanya kesenjangan yang terjadi antara kedua perspektif penilaian tersebut. Hasil perhitungan analisis kesenjangan (gap) dari keseluruhan variabel memiliki nilai negatif. Hal ini menunjukan bahwa kualitas aktual (performance) yang dirasakan oleh pengguna belum memenuhi kualitas ideal (importance) yang diharapkan. Seluruh variabel memiliki nilai selisih negatif yang menunjukan ada kesenjangan yang tidak baik antara apa yang dirasakan pengguna dengan apa yang diinginkan atau diharapakan oleh pengguna. Penelitian ini menunjukan perlunya upaya manajemen dari website UMKM dalam upaya meningkatkan kualitas website agar dapat memenuhi kesesuaian dari para pengguna.

\section{KESIMPULAN}

Berdasarkan hasil evaluasi kualitas layanan website UMKM dengan menggunakan instrumen WebQual 4.0 dan metode Importance-Performance Analysis (IPA), maka dapat diambil kesimpulan bahwa kualitas website UMKM di Malang belum sesuai dengan harapan pengguna. Terdapat perbedaan yang memperlihatkan adanya kesenjangan (gap) antara dua perspektif penilaian antara tingkat kinerja (performance) atau kualitas aktual yang dirasakan oleh pengguna dan tingkat kepentingan (importance) atau kualitas ideal yang diharapkan. Secara keseluruhan, selisih dari kedua perspektif penilaian ini atau gap bernilai negatif dengan nilai sebesar -0.091 . Berdasarkan penilaian ketiga dimensi pengukuran, dimensi usability memiliki nilai selisih -0.081 , dimensi Service Interaction memiliki nilai selisih atau gap sebesar 0. 083 dan dimensi Information Quality memiliki nilai selisih atau gap paling besar sebesar -0.109 . Berdasarkan hal tersebut dapat disimpulkan bahwa kualitas aktual yang dirasakan belum bisa memenuhi kualitas ideal yang diinginkan pengguna website UMKM di Malang terutama dari atribut kualitas yang berhubungan dengan informasi dalam website.
Menurut analisis empat kuadran, atribut kualitas yang menjadi prioritas utama perbaikan adalah informasi dengan tingkat detail yang tepat. Atribut informasi dapat dipercaya, keamanan dalam bertransaksi, informasi akurat, keamanan informasi pribadi, informasi dalam format yang sesuai , Informasi aktual, Informasi relevan dan mudah melakukan navigasi yang mana menjadi atribut yang tergabung dalam dimensi Information Quality dan Service Interaction yang juga perlu menjadi perhatian dari manajemen website UMKM di Malang

\section{DAFTAR PUSTAKA}

Himawan, H., Saefullah, A., \& Santoso, S. (2015). Analisa dan Perancangan Sistem Informasi Penjualan Online (E-Commerce) pada CV Selaras Batik Menggunakan Analisis Deskriptif. Scientific Journal of Informatics, 1(1), 53-63.

Kasali, Rhenald (Maret 2000). "Peluang Pasar eCommerce dan Bagaimana Menyiasatinya." Makalah Seminar Sukses Berbisnis di era Internet: Kiat Membangun Situs Web yang Populer. Hyatt Regency, Surabaya.

Wicaksono, Bayu Luhur, Adhi Susanto, and Wing Wahyu Winarno. "Evaluasi Kualitas Layanan Website Pusdiklat BPK RI Menggunakan Metode Webqual Modifikasian dan Importance Performance Analysis." MEDIA 19.1 (2012).

Yuliana, Oviliani. "Penggunaan Teknologi Internet dalam Bisnis." Jurnal Akuntansi dan Keuangan 2.1 (2004): 36-52.

Yola, Melfa, and Duwi Budianto. "Analisis kepuasan konsumen terhadap kualitas pelayanan dan harga produk pada supermarket dengan menggunakan metode Importance Performance Analysis (IPA)." Jurnal Optimasi Sistem Industri 12.12 (2013): 301-309.

http://suryaMalang.tribunnews.com/2018/04/14/um km-kota-Malang-terus-tumbuh-di-tengahkendala-klasik (diakses 15 september 2018) 